Article

\title{
Assessment of the Knowledge, Perceptions, and Reactions towards the African Apefly (Spalgis lemolea lemolea) in Tanzania
}

\author{
Sayuni P. Nasari *, Patrick A. Ndakidemi and Ernest R. Mbega
}

Department of Sustainable Agriculture, Biodiversity and Ecosystems Management, Nelson Mandela African Institution of Science and Technology, Arusha P.O. Box 447, Tanzania; patrick.ndakidemi@nm-aist.ac.tz (P.A.N.); ernest.mbega@nm-aist.ac.tz (E.R.M.)

* Correspondence: nasaris@nm-aist.ac.tz

Received: 8 December 2019; Accepted: 8 January 2020; Published: 28 January 2020

\begin{abstract}
This paper reports on farmers' knowledge, perceptions, and reactions towards the African apefly (Spalgis lemolea lemolea), which appeared to be associated with some vegetables in some locations in Tanzania. Information was obtained from a sample of 100 key respondents using a semi-structured questionnaire and from focus groups selected from key locations in five districts in the country with histories with the African apefly. Acute and sub-acute toxicity tests of the African apefly were performed on female Swiss hybrid mice (Mus musculus) to assess whether or not the African apefly was toxic to mammals. The mice were exposed to increasing apefly meal concentrations in acute and sub-acute tests, and signs of toxicity were observed for 14 and 28 days, respectively. Blood samples were collected by cardiac puncture for hematological and biochemical analysis. Gross and microscopic examinations of the internal organs were done. The survey results showed that $92.1 \%$ of the respondents perceived the African apefly as poisonous and had stopped consuming the vegetables associated with it. In the toxicity tests, however, no death or toxic signs were displayed, and there was no significant difference between the control and treated mice in weight, hematological parameters, and histo-pathological examination results. These findings strongly indicate that, despite the negative perception by farmers regarding the African apefly, it is not poisonous. However, further studies on how farmers can be trained to have a positive perception of the African apefly and how the insect can be conserved for further research regarding its role in Tanzania are recommended.
\end{abstract}

Keywords: knowledge; perceptions; Spalgis spp; biological pest control; acute toxicity test; histopathology

\section{Introduction}

Insects are a diverse and biologically successful group of animals on Earth [1,2]. They can broadly be categorized as insect pests and beneficial insects [3]. The former are insects that feed on plants or transmit diseases, hence causing losses to farmers; the latter are insects that contribute to ecosystem services as natural enemies, pollinators, scavengers, weed killers, and soil builders [2,3]. Natural biological control accounts for about $33 \%$ of pest control mechanisms in cultivated systems [2]. Such insects can be manipulated as part of integrated pest management programs through the importation and establishment of exotic natural enemy species, direct manipulation of species, or manipulation of their environments [2,4].

People's knowledge of insect species varies in quality and quantity depending on their interests in the subject, their environment, and the relevance of insects to their lives [5]. While entomologists devote their professional lives to the study of insects, some non-entomologists perceive insects as potentially dangerous and consequently have an unreasonable fear of them, i.e., entomophobia [6]. 
The lack of adequate knowledge about insects has accelerated non-target effects on beneficial insects from non-judicious use of pesticides [7]. Therefore, adequate knowledge and perception of insects is important for agricultural extension programs to minimize the deviations between scientific knowledge and farmers' knowledge.

Spalgis spp is a group of carnivorous butterflies that feed on different mealybug (Hemiptera: Pseudococcidae) species during their immature stages. Previous studies on Spalgis epius (Indian apefly) have indicated that the butterfly can be used in the bio-control of mealybugs [8,9]. Like other butterflies, the pupal stage of the apefly is inactive and possesses a unique phenotypic feature in that it resembles the face of a monkey-hence the name "apefly" [10]. Evidence suggests that the third-instar larvae of S. epius are able to consume larger quantities of prey compared to other larval stages [11-13]. In this context, the larvae of the African apefly (Spalgis lemolea lemolea) can also be useful biological control agents for mealybugs. However, many Tanzanian farmers hold negative perceptions towards this insect, especially its pupae; i.e., many perceive it as a life threat [14-16]. Empirical information regarding existing perceptions, knowledge, and reactions with respect to S. lemolea lemolea in Tanzania has not been reported. Understanding the prevailing state of knowledge and peoples' reactions toward the insect is of paramount importance in order to allow for appropriate interventions. Moreover, knowing whether the insects contain endotoxin substances assimilated through interactions with their prey (i.e., phytotoxins from plants that the prey feed on) is a critical step towards effective conservation and utilization of their potential. The objective of the present study was therefore to assess the existing knowledge, perceptions, and reactions toward S. lemolea lemolea and to conduct toxicity tests to determine its health implications.

\section{Materials and Methods}

\subsection{Study Areas}

A survey was conducted in five districts in Tanzania-namely, Mvomero, Iringa, Geita, Meru, and Shinyanga-representing five agro-ecological zones (Figure 1). Four sites were purposefully selected from each district according to previous reports of apefly emergence through news channels.

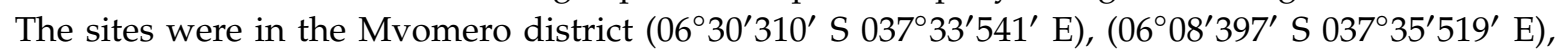

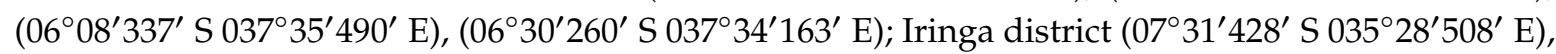
$\left(07^{\circ} 37^{\prime} 268^{\prime} \mathrm{S} 035^{\circ} 37^{\prime} 208^{\prime} \mathrm{E}\right),\left(07^{\circ} 38^{\prime} 325^{\prime} \mathrm{S} 035^{\circ} 36^{\prime} 072^{\prime} \mathrm{E}\right),\left(07^{\circ} 46^{\prime} 471 \mathrm{~S} \mathrm{E} 035^{\circ} 41^{\prime} 349^{\prime} \mathrm{E}\right)$; Geita district $\left(02^{\circ} 43^{\prime} 187^{\prime} \mathrm{S} 031^{\circ} 50^{\prime} 599^{\prime} \mathrm{E}\right),\left(02^{\circ} 43^{\prime} 186^{\prime} \mathrm{S} 031^{\circ} 50^{\prime} 596^{\prime} \mathrm{E}\right),\left(02^{\circ} 44^{\prime} 19.60^{\prime} \mathrm{S} 031^{\circ} 56^{\prime} 460^{\prime} \mathrm{E}\right)\left(02^{\circ} 53^{\prime} 614^{\prime} \mathrm{S}\right.$ $\left.32^{\circ} 13^{\prime} 529^{\prime} \mathrm{E}\right)$; Meru district $\left(03^{\circ} 24^{\prime} 312^{\prime} \mathrm{S} 036^{\circ} 48^{\prime} 515^{\prime} \mathrm{E}\right),\left(03^{\circ} 20^{\prime} 585^{\prime} \mathrm{S} 037^{\circ} 18^{\prime} 590^{\prime} \mathrm{E}\right),\left(03^{\circ} 23^{\prime} 451^{\prime} \mathrm{S}\right.$

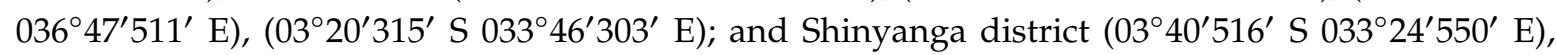
$\left(\mathrm{S}^{\circ} 3^{\circ} 37^{\prime} 523^{\prime} \mathrm{S} 033^{\circ} 5^{\prime} 49.92^{\prime} \mathrm{E}\right),\left(03^{\circ} 54^{\prime} 107^{\prime} \mathrm{S} 033^{\circ} 13^{\prime} 334^{\prime} \mathrm{E}\right),\left(03^{\circ} 48^{\prime} 365^{\prime} \mathrm{S} 033^{\circ} 20^{\prime} 400^{\prime} \mathrm{E}\right)$. For areas where records were lacking, the selection was based on information regarding mealybug infestations and/or the presence of crops prone to mealybug infestation.

\subsection{Survey}

A survey of the existing knowledge, perceptions, and reactions of Tanzanian farmers with respect to the African apefly was carried out between January and September 2018. A total of 100 key informants (20 respondents from each district) was purposefully selected for the interviews. A trained enumerator administered semi-structured questionnaires after pre-testing them for validity among households in the surveyed areas. Apart from verifying the validity of the questionnaire, the pre-testing was also used to familiarize the enumerator with the questionnaires as well as the survey. The collected information included: Participants' socio-economic profiles and their knowledge, perceptions, and reactions with respect to the African apefly. The respondents were also interviewed in the Swahili language. The questionnaires were discussed during face-to-face interviews and non-verbal communications were noted. 


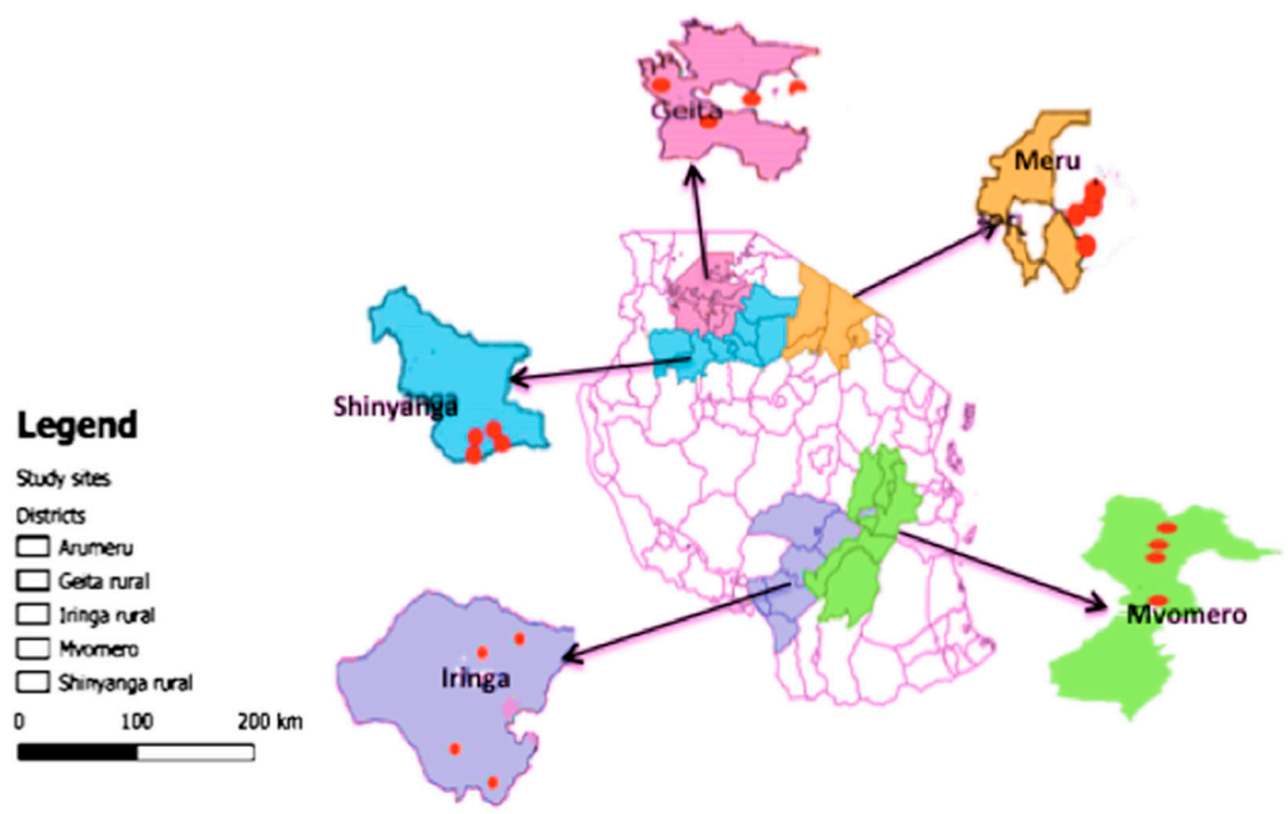

Figure 1. Map of Tanzania indicating the sites where the study was carried out.

\subsection{Toxicity Tests}

\subsubsection{Collection and Preparation of S. lemolea lemolea Pupa}

The S. lemolea lemolea pupae were collected from papaya plants in an organic garden located at Tengeru in Arusha, Tanzania (S $03^{\circ} 24^{\prime} 31.2^{\prime \prime}$ and E $\left.036^{\circ} 48^{\prime} 51.5^{\prime \prime}\right)$. Identification of the insect to the genus level was performed at the Tropical Pesticide Research Institute (TPRI), and the specimens were deposited at the National Insect Collection Reference Center (NICRC), Arusha, Tanzania. Molecular identification of the collected samples was carried out at the Nelson Mandela African Institution of Science and Technology, Arusha, Tanzania, and the insects were confirmed to be the African apefly (S. lemolea lemolea). The collected samples were pulverized into fine particles for feeding of mice, as displayed in Figure 2.

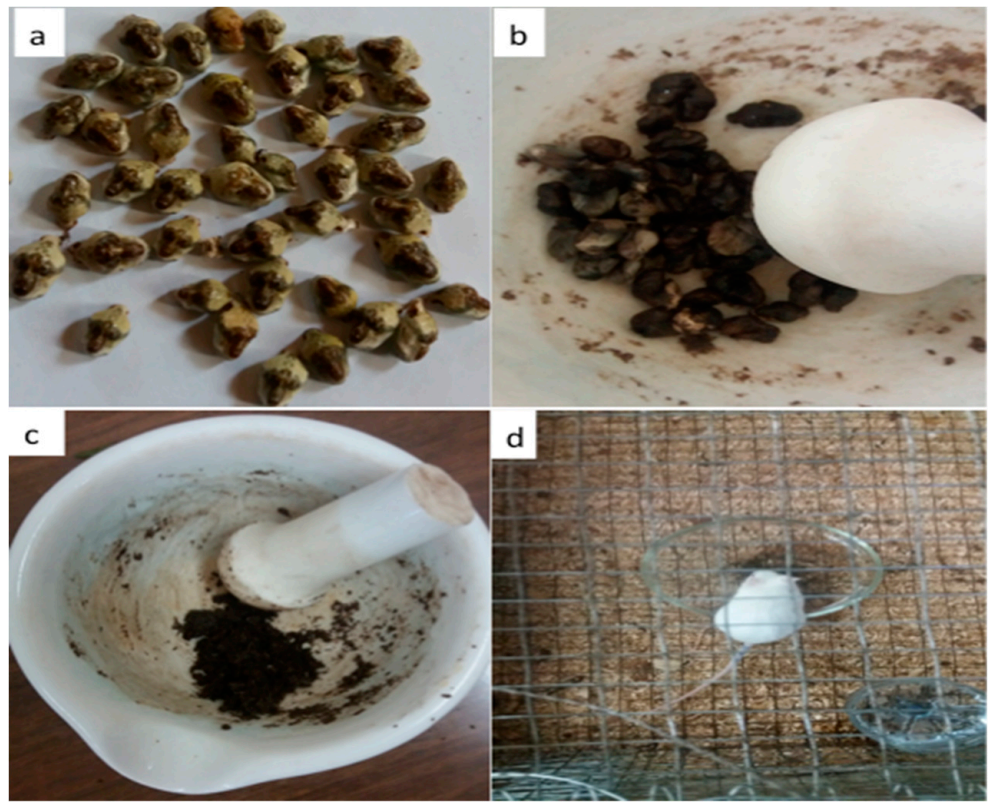

Figure 2. (a) S. lemolea lemolea pupae; (b) grinding of S. lemolea lemolea pupae; (c) S. lemolea lemolea meal; (d) a mouse feeding on $100 \%$ S. lemolea lemolea meal. 


\subsubsection{Experimental Animals}

Female Swiss albino mice (8-10 weeks old) with a mean weight of $27.12 \pm 0.54 \mathrm{~g}$ were randomly obtained from the Plant Protection Department of the TPRI based on their sensitivity to the toxic effects of chemicals than males [17]. An experiment was conducted to determine the daily food consumption rates of the mice prior to the experiment, and their $24 \mathrm{~h}$ food intake was obtained as the difference in weight between the food put in the cage and that remaining in the cage at the end of $24 \mathrm{~h}$, as described by Bunger et al. [18]. The mice were weighed, marked, and randomly allocated to specific experimental groups. They were fed with broiler mash and clean drinking water for 5 days prior to treatment to acclimatize them to the laboratory conditions. The experimental conditions were $25-30{ }^{\circ} \mathrm{C}, 40 \%-60 \%$ relative humidity, and $12 \mathrm{~h} \mathrm{light/dark.} \mathrm{The} \mathrm{mice} \mathrm{that} \mathrm{participated} \mathrm{in} \mathrm{the} \mathrm{acute} \mathrm{toxicity} \mathrm{test} \mathrm{were}$ continually provided with adequate feed and water even after terminating the experiment.

\subsubsection{Ethical Consideration}

An ethical clearance of the notification number KNCHREC0006 was obtained from the Northern Zone Health Research Ethics Sub-Committee (KNCHREC) of the National Institute for Medical Research (NIMR) in Tanzania. Similarly, the participants of the survey were requested for consent before interviews and focus group discussions.

\subsubsection{Acute Toxicity Tests}

A total of 9 healthy female albino mice were used following the Organization for Economic Cooperation and Development (OECD) guidelines for testing chemicals (1991). The mice were kept in $39 \times 17.5 \times 17.5 \mathrm{~cm}$ wire-mesh cages—one mouse per cage—and were provided with wood shavings as bedding. Since no prior toxicity test of the apefly had been performed, the mice were randomly allocated into 3 groups of 3 mice each-one control and 2 treatments. The control group received normal food (broiler mash) without the apefly meal, while the second group received $50 \%$ apefly meal plus $50 \%$ broiler mash, and the third group received $100 \%$ apefly meal. All mice were fasted for $4 \mathrm{~h}$ before being exposed to the treatments. After administration of the doses, the mice were individually examined in the first $30 \mathrm{~min}$ and after 1, 4, 12, and 24 h over a period of 14 days. All toxicity and recovery symptoms were noted. The observations included changes in skin, fur, eyes, respiratory activities, and behavioral patterns. Furthermore, attention was directed to observations of tremors, convulsions, salivation, diarrhea, lethargy, sleep, coma, and mortality. The principles and criteria summarized in the Humane Endpoints Guidance Document [19] were taken into consideration. Individual data were recorded in tabular form, and numerical results for the control and treated groups were compared to determine the health implications of the apefly meal consumption by the mice.

\subsubsection{Sub-Acute Toxicity Tests}

Sub-acute toxicity tests were carried out following OECD number 407. A total of 20 female albino mice were randomly allocated into 7 cages of 3 mice each. The mice were starved for $4 \mathrm{~h}$ and their weights were determined before treatment. Apefly meal was given at $0 \%, 50 \%, 75 \%$, and $100 \%$ daily for 28 days. The mice were carefully observed in the first $30 \mathrm{~min}$ and after 1, 4, 12, and $24 \mathrm{~h}$ over a period of 28 days. Their body weights were determined after every 7 days, and symptoms of toxicity such as changes in skin, fur, and eyes, respiratory activities, and behavior patterns were noted. Further attention was directed to observations of tremors, convulsions, salivation, diarrhea, lethargy, sleep, coma, and mortality.

\subsubsection{Hematological and Biochemical Examinations}

On the 28th day, all mice were individually weighed and subjected to chloroform anesthesia. Blood samples were collected from each of them by cardiac puncture into two types of tubes-with and without the anti-coagulant substance, ethylene diamine tetra acetic acid (EDTA). Hematological 
parameters including white blood cells (WBC), red blood cells (RBC), mean cell volume (MCV), mean cell hemoglobin $(\mathrm{MCH})$, mean cell hemoglobin concentration (MCHC), and hemoglobin concentration $(\mathrm{Hb})$ were determined using the blood samples in the EDTA tubes by an automatic hematology analyzer. The blood samples contained in the tubes without EDTA were centrifuged at $4000 \mathrm{rpm}$ for $10 \mathrm{~min}$, and the obtained serum was subjected to biochemical and liver function analysis for parameters such as alkaline phosphate (ALP), creatinine (cr), alanine aminotransferase (ALT), and aspartate aminotransferase (AST). After blood collection, all mice were sacrificed and dissected, and their organs-such as spleens, livers, kidneys, and hearts-were collected. The organs were cross-examined and comparisons were made between the control and treated mice groups. The organs were then weighed and preserved in 10\% neutral buffered formalin for histopathological examination.

\subsubsection{Histopathological Analysis}

The internal organs—such as spleens, hearts, kidneys, and livers—-were prepared for histopathology assessments. Three replicates of the liver, kidney, and spleen sections of $5 \mu \mathrm{m}$ per treatment were cut and processed by rapid manual tissue processing as described in Culling [20]. The processed sections were stained with hematoxylin and eosin (H\&E) and cover-slipped, following pre-described methodologies [20]. The slides were then observed under a light microscope and photomicrographs were captured for documentation.

\subsection{Statistical Analyses}

The survey data were summarized and descriptive statistics obtained using the Statistical Package for Social Science (SPSS) version 20. For each question, the percentage of farmers with similar responses was calculated for each site. Chi-square was used to assess the association of responses on knowledge and perceptions with respective districts in a bivariate analysis as cross-tabulation with their locations. The level of significance was set at $p<0.05$. One-way Analysis of variance (ANOVA) and post-hoc tests were conducted to test for significant differences in the weights of the mice that received different concentrations of the apefly meal during the acute and sub-acute toxicity tests. Toxicity data such as body and organ weight as well as hematological and biochemical parameters were also analyzed using descriptive statistics.

\section{Results}

\subsection{Survey Results}

Table 1 summarizes socio-economic profiles of the participants. Most of the respondents $(60 \%)$ were males and a majority (54\%) of them were aged between $41-60$ years, while $72 \%$ had professional training from either colleges or universities. About $52 \%$ of them were leaders at village and ward levels.

Out of the 100 participants, 89 were included in the analysis of knowledge; Table 2 summarizes the knowledge assessment responses. Among the respondents, only $38.2 \%$ reported to have encountered a living S. lemolea lemolea, while $61.8 \%$ had heard of the insect. A majority $(79.8 \%)$ of them reported to have known of the insect for the first time between 2010-2018, with the highest frequency in 2017, while a few (9\%) had known of the insect since the 1990s and 1980s. The media was the main source of information about S. lemolea lemolea for $83.1 \%$ of the respondents. Most respondents $(68.5 \%)$ had knowledge of other insects that are associated with S. lemolea lemolea, describing them as "white waxy insects" and "sticky insects", meaning mealybugs. However, $94.4 \%$ did not know the relationship between the mentioned insects and S. lemolea lemolea.

When the respondents were asked about their opinions on the potential dangers of S. lemolea lemolea to human health, $92.1 \%$ of them said that the apefly is dangerous based on what they heard through the media $(83.1 \%)$ and other sources $(16.9 \%)$. When asked about their emotional reactions towards the insect, $88.8 \%$ reported that the insect was scary and caused anxiety. About $86.5 \%$ were not satisfied by the interventions made by experts to address the anxiety when the insect availability was 
at its peak. Generally, a majority of the participants perceived the insect negatively, mainly due to its unusual appearance and the spreading news about its toxicity. These findings were similar across the districts, indicating that the insect was generally perceived negatively regardless of location. Despite the negative perceptions towards the insect, $88.8 \%$ of the surveyed respondents did not aggressively deal with $S$. lemolea lemolea, but rather avoided them by abstaining from vegetables associated with it for periods of about 3-5 months. This reportedly reduced vegetable consumption by about $60.7 \%$, which caused high losses to vegetable farmers, especially in Geita, as can be seen in Table 2.

The responses about knowledge, perceptions, and reactions were associated with respective districts in a bivariate analysis as cross-tabulation $(p<0.05)$. The findings are summarized in Table 3 .

Table 1. Socio-economic profiles of the participants $(n=100)$.

\begin{tabular}{ccc}
\hline Characteristics & $\mathbf{N}$ & $\mathbf{\%}$ \\
\hline Sex & & \\
Male & 60 & 60.0 \\
Female & 40 & 40.0 \\
Age (Years) & & \\
$21-40$ & 35 & 35.0 \\
$41-60$ & 54 & 54.0 \\
$\geq 61$ & 18 & 18.0 \\
Education & & \\
No Professional training & 28 & 28.0 \\
College & 54 & 54.0 \\
University & 18 & 18.0 \\
Occupation & & \\
Community leader/elders & 29 & 29.0 \\
Ward/Village staff & 52 & 52.0 \\
District staff & 17 & 17.0 \\
Regional staff & 2 & 2.0 \\
\hline
\end{tabular}

Table 2. Assessment of the existing knowledge, perceptions, and reactions with respect to the apefly $(n=89)$.

\begin{tabular}{|c|c|c|}
\hline Characteristics & $\mathbf{N}$ & $\%$ \\
\hline \multicolumn{3}{|l|}{ How did you know? } \\
\hline Encountered the insect & 34 & 38.2 \\
\hline Heard about the insect & 55 & 61.8 \\
\hline \multicolumn{3}{|l|}{ When? } \\
\hline 2010-2018 & 71 & 79.8 \\
\hline 2000-2009 & 10 & 11.2 \\
\hline Before 2000 & 8 & 9.0 \\
\hline \multicolumn{3}{|l|}{ In your farm? } \\
\hline Yes & 13 & 14.6 \\
\hline No & 76 & 85.4 \\
\hline \multicolumn{3}{|l|}{ In which season? } \\
\hline Wet season & 5 & 5.6 \\
\hline Dry season & 84 & 94.4 \\
\hline \multicolumn{3}{|c|}{ Interaction with other insects? } \\
\hline Yes & 61 & 68.5 \\
\hline No & 4 & 4.5 \\
\hline I don't know & 24 & 27.0 \\
\hline \multicolumn{3}{|c|}{ Is the apefly useful in agriculture? } \\
\hline Yes & 3 & 3.4 \\
\hline No & 2 & 2.2 \\
\hline I don't know & 84 & 94.4 \\
\hline \multicolumn{3}{|c|}{ Heard of anyone affected by the apefly? } \\
\hline Yes & 81 & 91.0 \\
\hline No & 8 & 9.0 \\
\hline \multicolumn{3}{|l|}{ Source of information? } \\
\hline Experts & 3 & 3.4 \\
\hline Media & 74 & 83.1 \\
\hline Farmers & 12 & 13.5 \\
\hline
\end{tabular}


Table 2. Cont.

\begin{tabular}{ccc}
\hline Characteristics & N & $\%$ \\
\hline Is the apefly poisonous? & 7 & 7.9 \\
No & 82 & 92.1 \\
Yes & 12 & 13.5 \\
Any intervention? & 77 & 86.5 \\
Yes & & \\
No & 6 & 6.7 \\
How do you deal with the apefly? & 4 & 4.5 \\
Chemical spray & 79 & 88.8 \\
$\quad$ Biological & & \\
Avoidance & 54 & 60.7 \\
$\quad$ Yes & 35 & 39.3 \\
$\quad$ No & & \\
Are farmers affected by the apefly? & 10 & 11.2 \\
How was your first reaction? & 79 & 88.8 \\
$\quad$ No reaction & & \\
Scared & &
\end{tabular}

Table 3. Knowledge, perception, and reactions in association with district $(n=89)$.

\begin{tabular}{|c|c|c|c|c|c|c|}
\hline & \multicolumn{6}{|c|}{ Districts n (\%) } \\
\hline & Meru & Geita & Mvomero & Shinyanga & Iringa & $\chi^{2}(p$-Value $)$ \\
\hline How did you know? & & & & & & $7.401(0.114)$ \\
\hline I saw & $7(35)$ & $9(45)$ & $11(61.1)$ & $5(23.8)$ & $2(20)$ & \\
\hline I heard & $13(65)$ & $11(55)$ & 7 (38.9) & $16(76.2)$ & $8(80)$ & \\
\hline When? & & & & & & $18.550(0.002) *$ \\
\hline 2010-2018 & $18(90)$ & $16(80)$ & $11(61.1)$ & $20(95.2)$ & $6(60)$ & \\
\hline 2000-2009 & $1(5)$ & - & $6(33.3)$ & - & $3(30)$ & \\
\hline Before 2000 & $1(5)$ & $4(20)$ & $1(5.6)$ & $1(4.8)$ & $1(10)$ & \\
\hline In your farm? & & & & & & $18.422(<0.001) *$ \\
\hline Yes & $2(10)$ & $2(10)$ & $9(50)$ & - & - & \\
\hline No & $18(90)$ & $18(90)$ & $9(50)$ & $21(100)$ & $10(100)$ & \\
\hline Interaction with other insects? & & & & & & $37.171(<0.001) *$ \\
\hline Yes & $15(75)$ & $20(100)$ & $14(77.8)$ & $8(38.1)$ & $4(40)$ & \\
\hline No & $4(20)$ & - & - & - & - & \\
\hline I don't know & $1(5)$ & - & $4(22.2)$ & $13(61.9)$ & $6(60)$ & \\
\hline In which season? & & & & & & $8.162(0.012) *$ \\
\hline Wet season & $4(20)$ & - & - & - & $1(10)$ & \\
\hline Dry season & $16(80)$ & $20(100)$ & $18(100)$ & $21(100)$ & $9(90)$ & \\
\hline Is the apefly useful? & & & & & & $6.020(0.755)$ \\
\hline Yes & $1(5)$ & $1(5)$ & $1(5.6)$ & - & - & \\
\hline No & - & - & - & $1(4.8)$ & $1(10)$ & \\
\hline I don't know & $19(95)$ & $19(95)$ & $17(94.4)$ & $20(95.2)$ & $9(90)$ & \\
\hline Heard of anyone affected by the apefly? & & & & & & $6.989(0.069)$ \\
\hline Yes & $20(100)$ & $19(95)$ & $16(88.9)$ & $16(76.2)$ & $10(100)$ & \\
\hline No & - & $1(5)$ & $2(11.1)$ & $5(23.8)$ & - & \\
\hline Source of information? & & & & & & $14.162(0.048) *$ \\
\hline Experts & - & $3(15)$ & - & - & - & \\
\hline Media & $18(90)$ & $12(60)$ & $14(77.8)$ & $20(95.2)$ & $10(100)$ & \\
\hline Farmers & $2(10)$ & $4(20)$ & $2(11.1)$ & $1(4.8)$ & - & \\
\hline No information & - & $1(5)$ & $2(11.1)$ & - & - & \\
\hline Is the apefly poisonous? & & & & & & $1.148(1.000)$ \\
\hline No & $1(5)$ & $2(10)$ & $1(5.6)$ & $2(9.5)$ & $1(10)$ & \\
\hline I don't know & $19(95)$ & $18(90)$ & $17(94.4)$ & $19(90.5)$ & $9(90)$ & \\
\hline Are farmers affected by the apefly? & & & & & & $49.554(<0.001) *$ \\
\hline Yes & $2(10)$ & $20(100)$ & $6(33.3)$ & $7(33.3)$ & - & \\
\hline No & $18(90)$ & - & $12(66.7)$ & $14(66.7)$ & $10(100)$ & \\
\hline Interventions? & & & & & & $16.262(<0.001) *$ \\
\hline Yes & $1(5)$ & $3(15)$ & $8(44.4)$ & - & - & \\
\hline No & $19(95)$ & $17(85)$ & $10(55.6)$ & $20(100)$ & $10(100)$ & \\
\hline How do you deal with the apefly? & & & & & & $37.378(<0.001) *$ \\
\hline Chemical spray & - & $3(15)$ & $3(16.7)$ & - & - & \\
\hline Biological & - & - & $4(22.2)$ & - & - & \\
\hline Avoidance & $20(100)$ & $17(85)$ & $11(61)$ & $20(100)$ & $11(100)$ & \\
\hline
\end{tabular}




\subsection{Toxicity Tests}

\subsubsection{Acute Toxicity}

The acute toxicity test of the apefly meal on albino mice revealed that the behavior of treated and control groups in the first $30 \mathrm{~min}$ and after $4 \mathrm{~h}, 24 \mathrm{~h}$, and daily up to the 14th day did not show any visible signs of acute toxicity. There was no decrease in weight or abnormal growth resulting from the consumption of apefly meal even at the $100 \%$ dose. Detailed observations are presented in Table 4.

One-way ANOVA and post-hoc tests were conducted to assess for significant differences in the weights of mice at different concentrations of the apefly meal. The findings showed significant differences $(p=0.030)$ in mice weight at day 0 but no significant differences $(p=0.149)$ were noted at day 14 (Table 5). The results generally revealed a gradual increase in the weight of mice for both control and treated groups. These observations imply that the apefly meal contains few or no toxic substances and could be tolerated even when consumed up to $100 \%$ concentration.

Table 4. Behavioral observations of the acute toxicity study of apefly meal on mice.

\begin{tabular}{|c|c|c|c|}
\hline Observation & $\begin{array}{c}\text { Control } \\
\text { (0\% Apefly Meal) }\end{array}$ & $\begin{array}{c}\text { Treatment } 1 \\
\text { (50\% Apefly Meal) }\end{array}$ & $\begin{array}{c}\text { Treatment } 2 \\
\text { (100\% Apefly Meal) }\end{array}$ \\
\hline Changes in skin and fur & Null & Null & Null \\
\hline Eyes & Normal & Normal & Normal \\
\hline Respiratory activity & Normal & Normal & Normal \\
\hline Tremors & Not observed & Not observed & Not observed \\
\hline Convulsion & Did not occur & Did not occur & Did not occur \\
\hline Salivation & Normal & Normal & Normal \\
\hline Drowsiness & Did not occur & Did not occur & Did not occur \\
\hline Comma & Did not occur & Did not occur & Did not occur \\
\hline Death & Did not occur & Did not occur & Did not occur \\
\hline
\end{tabular}

Table 5. Bodyweight (g) values of controls and mice treated with apefly diets during the acute toxicity test.

\begin{tabular}{|c|c|c|c|c|}
\hline Weight (g) & $\begin{array}{c}\text { Control } \\
\text { (0\% Apefly Meal) }\end{array}$ & $\begin{array}{c}\text { Treatment } 1 \\
\text { (50\% Apefly Meal) }\end{array}$ & $\begin{array}{c}\text { Treatment } 2 \\
\text { (75\% Apefly Meal) }\end{array}$ & $p$-Value \\
\hline Day 0 & $26.77 \pm 0.25$ & $28.20 \pm 0.66$ & $28.20 \pm 0.66$ & 0.030 \\
\hline Day14 & $33.23 \pm 0.68$ & $33.60 \pm 1.21$ & $31.83 \pm 1.01$ & 0.149 \\
\hline
\end{tabular}

Values are an average of three mice fed with the Apefly diet, expressed as mean \pm SEM.

\subsubsection{Sub-Acute Toxicity}

The results of the sub-acute toxicity study of the apefly meal on mice showed that there were no signs of toxicity in mice from both control and treated groups, even at $100 \%$ apefly meal concentrations. All animals were normal throughout the study period and all survived until the 28th day of experimentation. The values of all hematological parameters remained within normal limits, as summarized in Table 6. The results of hematological parameters of the control and treated mice showed no significant differences $(p>0.05)$ in all hematological parameters after 28 days of treatment with the apefly meal.

The results showed a gradual increase in the body weights of mice from day 0 to 28 . There was no significant difference $(p>0.05)$ in the means between the control and treatment groups, as can be seen in Table 7. Similarly, the organ weights, relative to the body weights of the mice, did not show any significant differences in weight changes of organs such as spleens, kidneys, and hearts between the control and mice treated with the apefly meal at all doses, except for the liver, which did not show any toxicity signs when subjected to histopathological examinations (Tables 8 and 9). 
Table 6. Hematological values of controls and mice treated with apefly diets during the sub-acute toxicity test.

\begin{tabular}{cccccc}
\hline Parameters & $\begin{array}{c}\text { Control } \\
\text { (0\% Apefly) }\end{array}$ & $\begin{array}{c}\text { Treatment 1 } \\
\text { (50\% Apefly) }\end{array}$ & $\begin{array}{c}\text { Treatment 2 } \\
\text { (75\% Apefly) }\end{array}$ & $\begin{array}{c}\text { Treatment 3 } \\
(\mathbf{1 0 0 \%} \text { Apefly) }\end{array}$ & $\boldsymbol{p}$-Value \\
\hline WBC M/mm & $4.81 \pm 0.2$ & $4.54 \pm 0.68$ & $4.62 \pm 0.18$ & $4.97 \pm 0.57$ & 0.474 \\
LYM\% & $80.8 \pm 1.3$ & $82.2 \pm 3.77$ & $85.8 \pm 7.09$ & $80.4 \pm 3.21$ & 0.233 \\
RBC M/mm 3 & $5.3 \pm 2.03$ & $5.72 \pm 2.64$ & $4.16 \pm 0.57$ & $4.37 \pm 0.51$ & 0.440 \\
MCV (pg) & $32.16 \pm 9.49$ & $36.82 \pm 11.26$ & $32.66 \pm 7.83$ & $41.1 \pm 18.59$ & 0.650 \\
MCH (pg) & $31 \pm 1.67$ & $31.46 \pm 2$ & $31.26 \pm 0.67$ & $30.08 \pm 2.38$ & 0.639 \\
MCHC (g/dL) & $32.5 \pm 0.38$ & $32.62 \pm 0.68$ & $33.12 \pm 2.35$ & $31.96 \pm 1.43$ & 0.652 \\
Hb (g/dL) & $14.1 \pm 1.58$ & $12.94 \pm 1.1$ & $13.7 \pm 2.37$ & $13.18 \pm 1.38$ & 0.699 \\
\hline
\end{tabular}

Values are expressed as mean \pm SEM; $\mathrm{WBC}=$ white blood cell, $\mathrm{RBC}=$ red blood cell, $\mathrm{MCV}=$ mean corpuscular volume, $\mathrm{LYM}=$ lymphocytes, $\mathrm{MCH}=$ mean corpuscular hemoglobin, $\mathrm{MCHC}=$ mean corpuscular hemoglobin concentration, and $\mathrm{Hb}=$ hemoglobin.

Table 7. Body weight (g) values of the control and mice treated with apefly meal during the sub-acute toxicity test.

\begin{tabular}{|c|c|c|c|c|c|}
\hline Weight (g) & $\begin{array}{c}\text { Control } \\
\text { (0\% Apefly Meal) }\end{array}$ & $\begin{array}{c}\text { Treatment } 1 \\
\text { (50\% Apefly Meal) }\end{array}$ & $\begin{array}{c}\text { Treatment } 2 \\
\text { (75\% Apefly Meal) }\end{array}$ & $\begin{array}{c}\text { Treatment } 3 \\
\text { (100\% Apefly Meal) }\end{array}$ & $p$-Value \\
\hline Day 0 & $27.12 \pm 0.54$ & $27.92 \pm 0.62$ & $27.76 \pm 0.64$ & $27.92 \pm 0.62$ & 0.158 \\
\hline Day 14 & $33.66 \pm 0.87$ & $33.32 \pm 1.22$ & $33.72 \pm 1.80$ & $32.40 \pm 1.07$ & 0.369 \\
\hline Day 28 & $42.20 \pm 1.38$ & $40.72 \pm 2.22$ & $41.68 \pm 3.36$ & $38.88 \pm 2.36$ & 0.187 \\
\hline
\end{tabular}

Table 8. Average organ weight values of the control and mice treated with apefly meal measured during the sub-acute toxicity study.

\begin{tabular}{|c|c|c|c|c|c|}
\hline Organ & $\begin{array}{c}\text { Control } \\
(0 \% \text { Apefly Meal) }\end{array}$ & $\begin{array}{c}\text { Treatment } 1 \\
\text { (50\% Apefly Meal) }\end{array}$ & $\begin{array}{c}\text { Treatment } 2 \\
\text { (75\% Apefly Meal) }\end{array}$ & $\begin{array}{c}\text { Treatment } 3 \\
\text { (100\% Apefly Meal) }\end{array}$ & $p$-Value \\
\hline Spleen & $0.2 \pm 0$ & $0.18 \pm 0.02$ & $0.18 \pm 0.1$ & $0.16 \pm 0.03$ & 0.807 \\
\hline Liver & $1.96 \pm 0.01$ & $1.97 \pm 0.01$ & $1.99 \pm 0.03$ & $1.97 \pm 0.02$ & 0.001 \\
\hline Kidney & $0.57 \pm 0.01$ & $0.56 \pm 0.01$ & $0.57 \pm 0.02$ & $0.55 \pm 0.01$ & 0.281 \\
\hline Heart & $0.17 \pm 0.01$ & $0.17 \pm 0.01$ & $0.34 \pm 0.38$ & $0.17 \pm 0.01$ & 0.425 \\
\hline
\end{tabular}

Table 9. Relative organ weight values of the control and mice treated with apefly meal measured during sub-acute toxicity study.

\begin{tabular}{cccccc}
\hline Organ & $\begin{array}{c}\text { Control } \\
\text { (0\% Apefly Meal) }\end{array}$ & $\begin{array}{c}\text { Treatment 1 } \\
\mathbf{5 0 \%} \text { Apefly Meal) }\end{array}$ & $\begin{array}{c}\text { Treatment 2 } \\
\mathbf{( 7 5 \% ~ A p e f l y ~ M e a l ) ~}\end{array}$ & $\begin{array}{c}\text { Treatment 3 } \\
\text { (100\% Apefly Meal) }\end{array}$ & $\boldsymbol{p}$-Value \\
\hline Spleen & $0.46 \pm 0.01$ & $0.44 \pm 0.04$ & $0.41 \pm 0.2$ & $0.42 \pm 0.05$ & 0.859 \\
Liver & $3.94 \pm 0.11$ & $4.86 \pm 0.24$ & $4.79 \pm 0.32$ & $5.08 \pm 0.27$ & $<0.001$ \\
Kidney & $1.35 \pm 0.03$ & $1.38 \pm 0.05$ & $1.36 \pm 0.07$ & $1.43 \pm 0.07$ & 0.174 \\
Heart & $0.41 \pm 0.01$ & $0.43 \pm 0.01$ & $0.77 \pm 0.78$ & $0.43 \pm 0.01$ & 0.422 \\
\hline
\end{tabular}

Values are an average from five mice fed with the apefly meal, expressed as mean \pm SEM.

\subsubsection{Biochemical and Microscopic Examinations}

The results of the kidney and liver function tests revealed no significant differences $(p>0.05)$ for concentrations in alkaline phosphate, creatinine, and liver hepatic enzymes AST and ALT (Table 10). The consumption of apefly meal was found to maintain the biochemical parameters within reasonable limits.

Microscopic examination of the main internal organs of animals such as livers, kidneys, spleens, and hearts also revealed no differences between the control and treated groups of mice even after administration of $100 \%$ apefly meal for 28 days. The photomicrographs of some organs are displayed in Figures 3 and 4. 

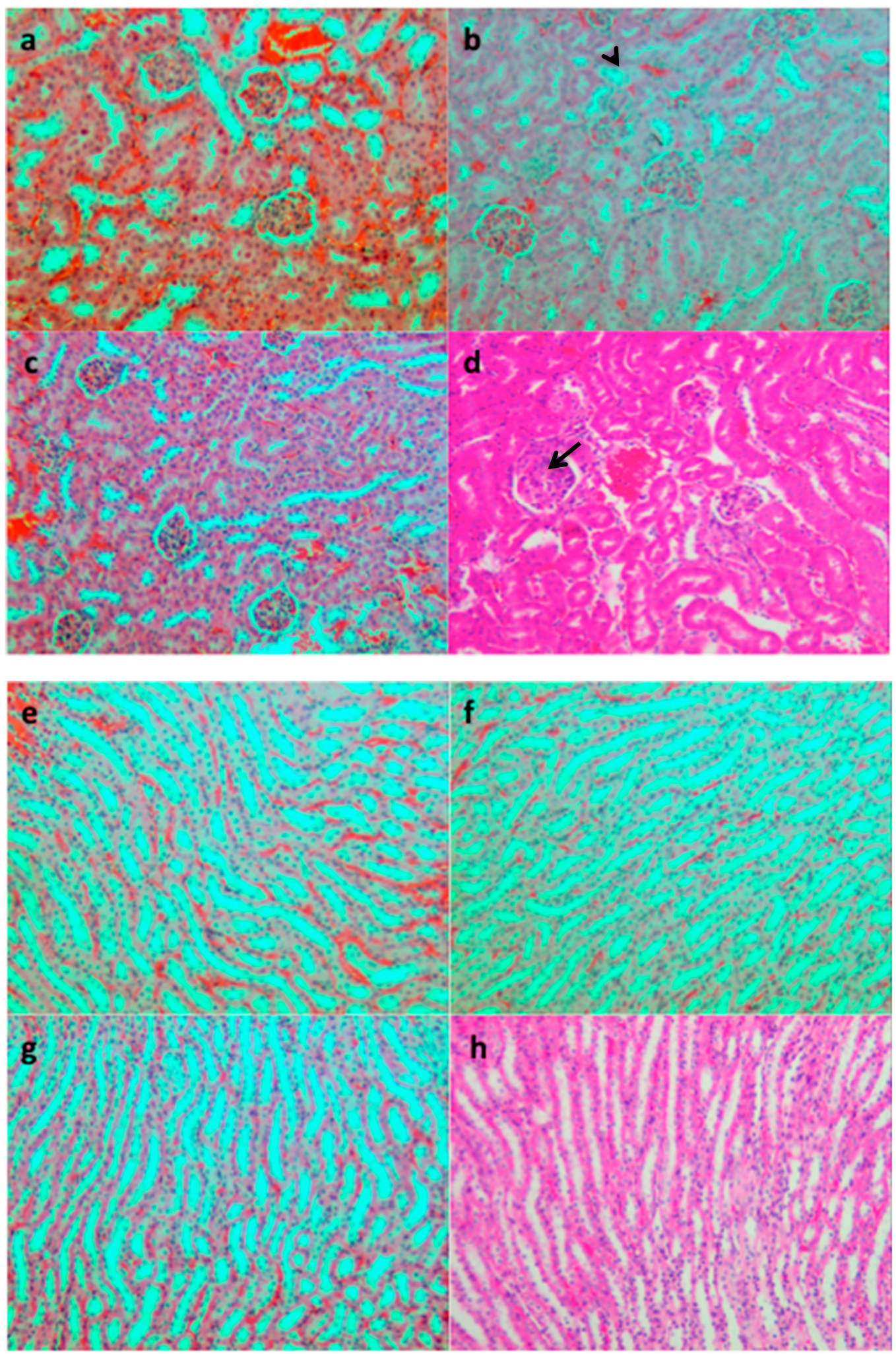

Figure 3. Photomicrographs of the renal cortex $(\mathbf{a}=$ Control, $\mathbf{b}=50 \%$ apefly meal, $\mathbf{c}=75 \%$ apefly meal, and $\mathbf{d}=100 \%$ apefly meal) and renal medulla ( $\mathbf{e}=$ Control, $\mathbf{f}=50 \%$ apefly meal, $\mathbf{g}=75 \%$ apefly meal, and $\mathbf{h}=100 \%$ apefly meal. The renal cortexes of both controls and treated groups showed normal glomeruli (arrow heads) with mild congestion (arrows). Congestion was also seen in the medullas of controls and treated groups (magnification 10x). 


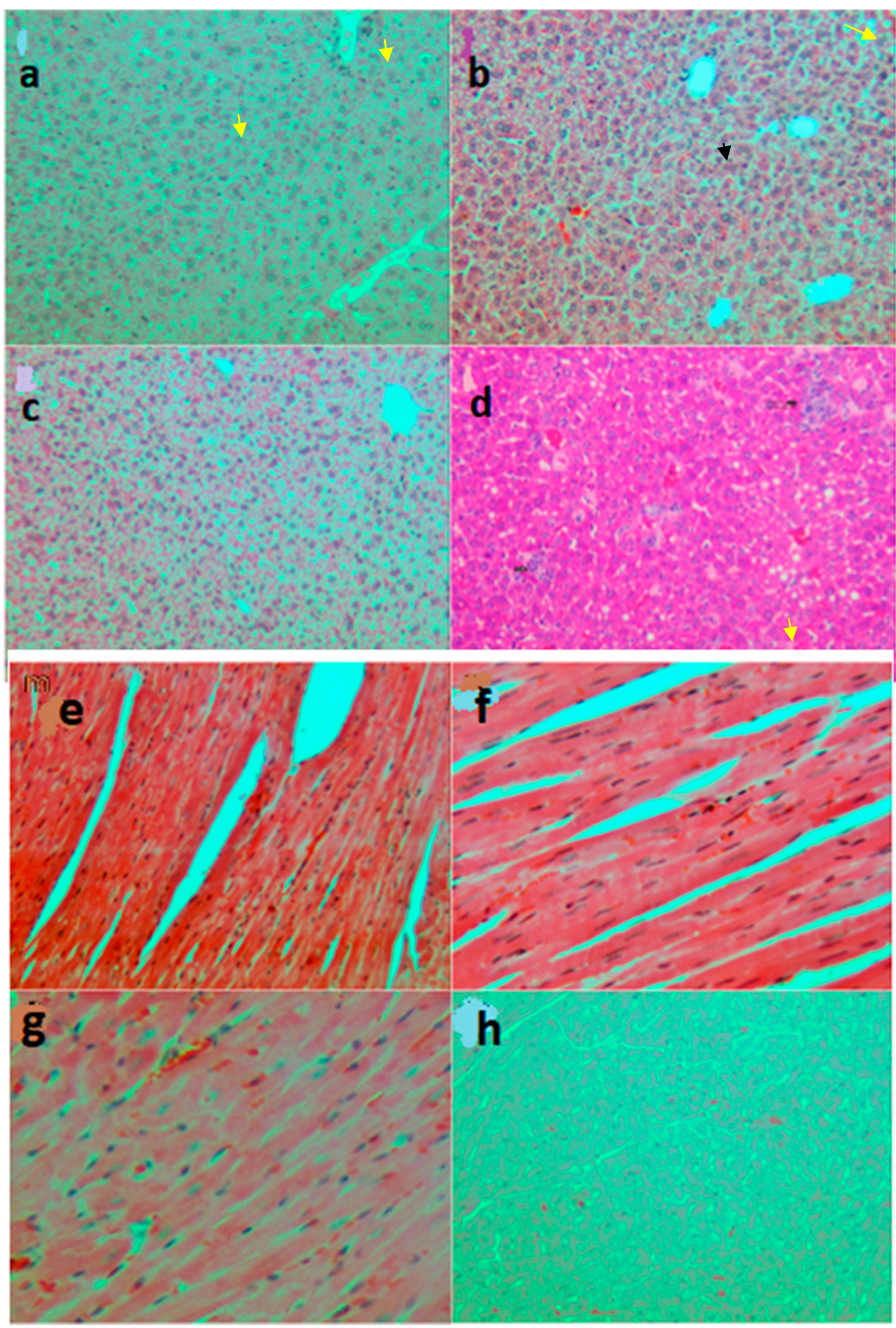

Figure 4. Representative photomicrographs of the liver section ( $a=$ Control, $\mathbf{b}=50 \%$ apefly meal, $\mathbf{c}=75 \%$ apefly meal, and $\mathbf{d}=100 \%$ apefly meal) and heart section (e=Control, $\mathbf{f}=50 \%$ apefly meal, $\mathbf{g}=75 \%$ apefly meal, and $\mathbf{h}=100 \%$ apefly meal). The liver and cardiac muscles of both controls and treated groups have similar microscopic morphologies that appear to be normal. Distention of sinusoidal and deranged cytoplasm observed in tissue sections of the liver is considered artifactual. 
Table 10. Values of biochemical parameters of the control and mice treated with apefly meal during the sub-acute toxicity test.

\begin{tabular}{|c|c|c|c|c|c|}
\hline Parameters & $\begin{array}{c}\text { Control } \\
\text { (0\% Apefly Meal) }\end{array}$ & $\begin{array}{c}\text { Treatment } 1 \\
\text { (50\% Apefly Meal) }\end{array}$ & $\begin{array}{c}\text { Treatment } 2 \\
\text { (75\% Apefly Meal) }\end{array}$ & $\begin{array}{c}\text { Treatment } 3 \\
\text { (100\% Apefly Meal) }\end{array}$ & $p$-Value \\
\hline Ap & $64.8 \pm 1.30$ & $65.4 \pm 2.70$ & $64.8 \pm 0.84$ & $64.2 \pm 1.10$ & 0.727 \\
\hline $\mathrm{Cr}$ & $0.88 \pm 0.12$ & $0.98 \pm 0.24$ & $0.8 \pm 0.05$ & $0.86 \pm 0.17$ & 0.373 \\
\hline AST & $22.84 \pm 3.00$ & $18.26 \pm 3.04$ & $23.18 \pm 11.04$ & $23 \pm 4.48$ & 0.562 \\
\hline ALT & $21.24 \pm 2.57$ & $18.68 \pm 1.17$ & $19.52 \pm 1.53$ & $18.86 \pm 1.31$ & 0.120 \\
\hline
\end{tabular}

Values are an average from five mice fed with the apefly diet, expressed as mean \pm SEM.

\section{Discussion}

\subsection{Knowledge, Perceptions, and Reactions about the Apefly}

This study assessed the existing knowledge, perceptions, and reactions about the African apefly (S. lemolea lemolea), Lepidoptera, Lycaenidae, subfamily Milletinae. The aim was to identify what is known, perceived, and done in relation to the apefly. The results revealed a lack of knowledge on this insect due to inadequate information. This can be attributed to the lack of research and the "uncommonness" of the apefly, which was reported by a majority of respondents in the field. However, this "uncommonness" was not always the case, since the apefly samples were collected from 65\% of the respondents' fields, revealing their ignorance of the presence of this insect in their fields. The respondents' attention was centered on the pupal apefly which has a monkey-face appearance, but none of them showed awareness of the pre-and post-pupal life stages of the apefly. The respondents identified cassava and papaya as the plant species that harbored S. lemolea lemolea. Although the host plants differed slightly in different localities, the common factor for all of them was the mealybug infestation. None of the respondents were aware of the carnivorous nature of S. lemolea lemolea larvae and their potential in pest control.

Most respondents had the negative opinion that the $S$. lemolea lemolea pupal stage is poisonous. Their main source of information was the media and fellow farmers in their localities. However, the negative attitude towards the insect had no supportive evidence from the respondents and could only be linked to its strange appearance, as supported by Wagler and Wagler [1]. The spreading information was noted to have significantly impacted the farmers' perceptions and decision-making, creating anxiety especially in remote areas where vegetables are consumed on a daily basis. However, it was observed that, despite the negative attitude towards the apefly, no aggressive response towards the insect had been reported. For example, about $88.8 \%$ of the respondents avoided the consumption of vegetables associated with the apefly, as supported by Curtis and Mannheimer [21]. In view of these findings, evaluation of the apefly's toxicity status is of paramount importance to scientifically proving whether it contains any poisonous compounds that can affect human health if accidentally consumed in the vegetables.

\subsection{Toxicity Tests}

A great number of arthropods are poisonous, and their toxins arouse complex and sometimes fatal manifestations in human beings [22]. They produce toxins for defense when touched, pressed, or crushed, while others inject venom by using a specialized apparatus. Literature shows that insects can acquire biochemicals from the food they consume or through contact with insecticides and herbicides [23]. For instance, some lepidopterans such as monarch butterflies (Danaus plesippus) accumulate certain poisons, called cardiac glucosides, from their host plants [24]. This study evaluated the in vivo effects of the apefly on mice upon ingestion to determine whether it contains endotoxins assimilated by interacting with their prey (i.e., phytotoxins from plants that the prey feed on).

Further investigations of the weight of the mice indicated that the apefly did not affect the bodyweight of the treated mice when compared to the control mice. The increasing weight shown by 
mice even at $100 \%$ apefly meal concentration provides evidence that the consumption of apefly did not affect the growth of the mice. According to Raza et al. [25] and Teo et al. [26], the reduction in weight gain is an important indicator of toxicity after exposing animals to toxic substances, and this is usually significant if weight loss exceeds $10 \%$ of the initial weight.

Blood analysis was done to determine the physiological and pathological status in the hematological system. Parameters such as RBCs, WBCs, LYs, and $\mathrm{Hb}$ were screened to investigate if the normal ranges of these parameters were altered from the intake of apefly meal. Studies show that the normal ranges of these parameters can be altered by the intake of toxic substances [27]. The results from this study showed that acute and sub-acute ingestion of the apefly meal did not cause any change in these hematological parameters for both the control and treated mice. Similarly, ingestion of toxic substances is manifested in the alteration of biochemical parameters that are sensitive indicators of metabolic defects [28]. In this study, parameters such as ALP, creatinine, and the liver hepatic enzymes AST and ALT showed no significant deviations from the normal ranges in both the control and treatment groups, suggesting that the apefly meal had no effects on mouse liver function.

Similarly, internal organs such as the livers, lungs, hearts, and kidneys were examined to find out any possible defects in metabolic reactions caused by the toxicants. The results showed no organ abnormalities observed between the normal and treatment groups. Similarly, the organ weights were compared to diagnose whether they were exposed to injuries or infections [29]. The results showed that the differences in weights of internal organs were not statistically significant in either the control or treated groups of mice, indicating that the apefly is non-toxic.

\section{Conclusions}

The lack of knowledge and negative attitudes towards insects that farmers encounter in their farms can threaten the status of some beneficial insects. This study provides evidence of the nontoxic effects of the apefly meal on mice. No mortality or toxicity was observed in mice treated with apefly meal, even at 100\% concentration. The hematological and biochemical analyses also showed no significant differences $(p=0.05)$ between the control and treated groups of mice. Furthermore, the apefly meal did not cause any damage to the vital body organs and therefore can be considered as relatively safe. This study calls for extensive studies on the apefly, including its biology and biological control potential on mealybugs, and the dissemination of proper information to the general public.

Author Contributions: Conceptualization, S.P.N.; methodology, S.P.N., E.R.M., and P.A.N.; Field investigations and data collection, S.P.N.; writing-original draft preparation, S.P.N.; writing-review and editing, S.P.N., E.R.M., and P.A.N.; supervision, E.R.M. and P.A.N.; project administration, S.P.N.; funding acquisition, S.P.N. All authors have read and agreed to the published version of the manuscript.

Funding: This research was funded by the AFRICAN DEVELOPMENT BANK, Grant number 210015503281.

Acknowledgments: This article is part of the research project called 'The Role, diversity, and farmers perception of Spalgis spp. in Tanzania', which is funded by the African Development Bank (AfDB).

Conflicts of Interest: The authors declare no conflict of interest. The funders had no role in the design of the study; in the collection, analyses, or interpretation of data; in the writing of the manuscript, or in the decision to publish the results.

\section{References}

1. Wagler, R.; Wagler, A. External insect morphology: A negative factor in attitudes toward insects and likelihood of incorporation in future science education settings. Int. J. Environ. Sci. Educ. 2012, 7, 313-325.

2. Getanjaly, V.L.R.; Sharma, P.; Kushwaha, P. Beneficial insects and their value to agriculture. Res. J. Agric. For. Sci. 2015, 3, 25-30.

3. Gredler, G. Encouraging Beneficial Insects in Your Garden; Oregon State University Extension Service: Covallis, OR, USA, 2001. 
4. Pickett, C.H.; Bugg, R.L. Enhancing Biological Control: Habitat Management to Promote Natural Enemies of Agricultural Pests; University of California Press: Berkeley, CA USA; Los Angeles, CA, USA; London, UK, 1998; p. 422.

5. Gurung, A.B. Insects-A mistake in God's creation? Tharu farmers' perception and knowledge of insects: A case study of Gobardiha Village Development Committee, Dang-Deukhuri, Nepal. Agric. Hum. Values 2003, 20, 337-370. [CrossRef]

6. Day, J.F.; Edman, J.D.; Kunz, S.E.; Wikel, S.K. Direct Injury: Phobias, Psychoses, Annoyance, Allergies, Toxins, Venoms and Myiasis. In Medical Entomology: A Textbook on Public Health and Veterinary Problems Caused by Arthropods; Eldrige, B.F., Edman, J.D., Eds.; Kluwer Academic Publishers: Dordrecht, The Netherlands, 2000; pp. 99-149.

7. Gavkare, O.M.; Sharma, P.L. New record of Nesidiocoris tenuis (Reuter) (Hemiptera: Miridae) associated with Bemisia tabaci Gennadius (Hemiptera: Aleyrodidae) on tomato from Maharashtra, India. J. Biol. Control 2014, 28, 53-54.

8. Dinesh, A.; Venkatesha, M. Prey consumption by the mealybug predator Spalgis epius on pink hibiscus mealybug (Maconellicoccus hirsutus). Phytoparasitica 2011, 39, 11-17. [CrossRef]

9. Saengyot, S.; Burikam, I. Bionomics of the apefly Spalgis epius (Lepidoptera: Lycaenidae) predatory on the papaya mealybug Paracoccus marginatus (Hemiptera: Pseudococcidae) in Thailand. Songklanakarin J. Sci. Technol. 2012, 34, 17.

10. Ackery, P.R. Bio control potential of African lycaenid butterflies entomophagous on Homopterous. J. Afr. Zool. 1990, 104, 582-591.

11. Kumar, P.K.V.; Vasudev, V.; Seetharama, H.G.; Irulandi, S.; Sreedharan, K. Biology and biometry of the Lycaenid predator Spalgis epius. J. Coffee Res. 2006, 34, 72-104.

12. Lohman, D.J.; Samarita, V.U. The biology of carnivorous butterfly larvae (Lepidoptera: Lycaenidae: Miletinae: Miletini) and their ant-tended hemipteran prey in Thailand and the Philippines. J. Nat. Hist. 2009, 43, 569-581. [CrossRef]

13. Tanwar, R.K.; Jeyakumar, P.; Vennila, S. Papaya Mealybug and Its Management Strategies; National Centre for Integrated Pest Management: New Delhi, India, 2010; p. 26. Available online: http://www.ncipm.res.in/ NCIPMPDFs/Publication/Swarming_caterpillar.pdf (accessed on 22 October 2019).

14. Athumani, M. Kidudu Mtu Ndio Hiki 2017. Available online: https://www.youtube.com/watch?v=XzUFOMHn5A (accessed on 30 June 2019).

15. Brown, S. Huyu Ndo Kidudu Mtu Anaesemekana Kusumbua Walaji Wa Matunda Na Mboga Mboga 2017. Available online: https://www.youtube.com/watch?v=DvUPUpcwXP0 (accessed on 18 June 2019).

16. Choke, S. www Geita info Mboga. 2017. Available online: https://www.youtube.com/watch?v= OCfDbRAR678 (accessed on 9 June 2019).

17. Organization for Economic Cooperation and Development (OECD). Acute oral toxicity: Up-and-Down procedure. In Guidelines for Testing of Chemicals; OECD Publishers: Paris, France, 2001. Available online: https://ntp.niehs.nih.gov/iccvam/suppdocs/feddocs/oecd/oecdtg425.pdf (accessed on 18 July 2019).

18. Bunger, M.K.; Moran, S.M.; Glover, E.; Thomae, T.L.; Lahvis, G.P.; Lin, B.C.; Bradfield, C.A. Resistance to 2, 3, 7, 8-tetrachlorodibenzo-p-dioxin toxicity and abnormal liver development in mice carrying a mutation in the nuclear localization sequence of the aryl hydrocarbon receptor. J. Biol. Chem. 2003, 278, 17767-17774. [CrossRef]

19. Demers, G.; Griffin, G.; De Vroey, G.; Haywood, J.; Zurlo, J.; Bedard, M. Harmonization of animal care and use guidance. Science 2006, 5774, 700-701. [CrossRef] [PubMed]

20. Culling, C. Handbook of Histopathological and Histochemical Techniques (Including Museum Techniques), 3rd ed.; Butterworth and Co. Ltd.: London, UK, 1974; p. 419.

21. Curtis, B.A.; Mannheimer, C.A.; Loutit, B. Tree Atlas of Namibia; National Botanical Research Institute: Windhoek, Namibia, 2005; pp. 406-407.

22. Haddad, J.V.; Amorim, P.C.H.D.; Junior, H.; Teixera, W.; Cardoso, J.L.C. Venomous and poisonous arthropods: Identification, clinical manifestations of envenomation, and treatments used in human injuries. Rev. Soc. Bras. Med. Trop. 2015, 6, 650-657. [CrossRef] [PubMed]

23. Longley, M.; Sotherton, N.W. Factors determining the effects of pesticides upon butterflies inhabiting arable farmland. Agric. Ecosyst. Environ. 1997, 61, 1-12. [CrossRef] 
24. Schreiner, I.H.; Donald, M.N. Butterflies of Micronesia. 1997, pp. 1-40. Available online: https://cnas-re.uog. edu/wp-content/uploads/2016/03/ButterfliesOfMicronesia.pdf (accessed on 12 November 2019).

25. Raza, M.; Al-Shabanah, O.A.; El-Hadiyah, T.M.; Al Majeed, A.A. Effect of prolonged vigabatrin treatment on hematological and biochemical parameters in plasma, liver and kidney of Swiss albino mice. J. Sci. Pharm 2002, 70, 135-145. [CrossRef]

26. Teo, S.D.; Stirling, S.; Thomas, A.; Kiorpes, A.; Vikram, K. A 90-day oral gavage toxicity study of D-methylphenidate and D, L methylphenidate in Sprague-dawley rats. Toxicology 2002, 179, 183-196. [CrossRef]

27. Ajagbonna, O.P.; Onifade, K.I.; Suleiman, U. Hematological and biochemical changes in rats given extract of Calotropis procera. Sok. J. Vet. Sci. 1999, 1, 36-42.

28. Reddy, R.R.; Lokanatha, O.; Ratnam, K.; Reddy, C.S.; Raju, I.N.; Reddy, C.D. Acute and sub-acute toxicity of Moringa oleifera stem bark extract in Swiss albino mice. Int. J. Sci. Biotech. Pharm. Res. 2013, 4, 74-82.

29. Shah, R.; Parmar, S.; Bhatt, P.; Chandra, S. Evaluation of hepatoprotective activity of ethyl acetate fraction of Tephrosia purpurea. Pharmacology 2011, 3, 188-194.

(C) 2020 by the authors. Licensee MDPI, Basel, Switzerland. This article is an open access article distributed under the terms and conditions of the Creative Commons Attribution (CC BY) license (http://creativecommons.org/licenses/by/4.0/). 